\title{
On Right Node Raising in Catalan and Spanish*
}

\author{
Vidal Valmala
}

UPV/EHU. Ingeles eta Aleman Filologiak eta Itzulpengintza

vidal.valmala@ehu.es

\begin{abstract}
The derivation of Right Node Raising (RNR) has been the object of much debate in the generative literature, but the analysis of this construction has not received much attention so far in the literature on Catalan and Spanish. Here I analyze the properties of RNR in these languages and propose that the distinction introduced in Valmala (2012) for English RNR also applies: Catalan and Spanish are argued to have two types of RNR with different information-structural, prosodic, and syntactic properties. In Focal-Pivot RNR (FP-RNR), the pivot is focal, is preceded by a prosodic break, and undergoes ATB-movement from both conjuncts of the coordination, i.e. it is ex-situ. In Non-Focal-Pivot RNR (NFP-RNR), on the contrary, the pivot is not focal, is not preceded by a prosodic break, and occupies its canonical position, i.e it is in-situ. NFP-RNR is the result either of ellipsis in the first conjunct or of multidominance of the pivot.
\end{abstract}

Keywords: Right Node Raising; ATB-movement; focus; ellipsis; multidominance; parenthetical; Catalan; Spanish.

\section{Table of Contents}

\author{
1. Two Types of Right Node Raising \\ 3. Conclusions \\ 2. (FP and NFP)-RNR \\ References \\ in Catalan and Spanish
}

* This research has been funded by the University of the Basque Country (UPV/EHU) (UFI11/14), the Basque Government (grants GIC07/144-IT-210-07, and HM-2009-1-1), and the Spanish Ministry of Science and Innovation (grant FFI-29218/FILO). I would like to thank an anonymous reviewer and the audience at LingLunch Paris 7 for their comments and suggestions. Francesc Roca deserves my deepest gratitude for both his judgements on Spanish and Catalan data and for his valuable comments and suggestions. Of course, all remaining errors are mine. 


\section{Two Types of Right Node Raising}

Right Node Raising (RNR) is the phenomenon in which there is a gap in final position of the non-final conjunct(s) of a coordination whose interpretation is determined by material overtly realized in the final conjunct of the coordination. The phenomenon is illustrated in (1), where the complement of verb in the first clause is not overtly realized and is interpreted as identical to the object of the verb in the second clause (the dishes). Following Postal (1998), the overt counterpart in the final conjunct of the missing material in the non-final conjunct(s) will be called the pivot. The crucial empirical fact that any approach to the analysis of RNR must account for is the impossibility of having the pivot in the initial conjunct and the gap in the non-initial conjunct(s) (2).

(1) John washed and Mary dried the dishes.

[Koutsoudas (1971: 352)]

(2) *John washed the dishes and Mary dried.

The syntactic representation of RNR has been the object of much debate in the generative literature. Four approaches to the analysis of RNR can be distinguished, the most important point of disagreement being whether the pivot is ex-situ or in-situ, i.e. moved or in its canonical position.

For some (Ross 1967; Maling 1972; Postal 1974, 1998; Hudson 1976; Sabbagh 2007; Clapp 2008; Abe and Hornstein 2012; among others) the pivot is ex-situ as a result of a rightward ATB-movement operation. Under this approach the representation of (1) is as in (3), where the pivot has ATB-moved to some position outside the coordination, represented here as a $\mathrm{CP}$-adjoined position.

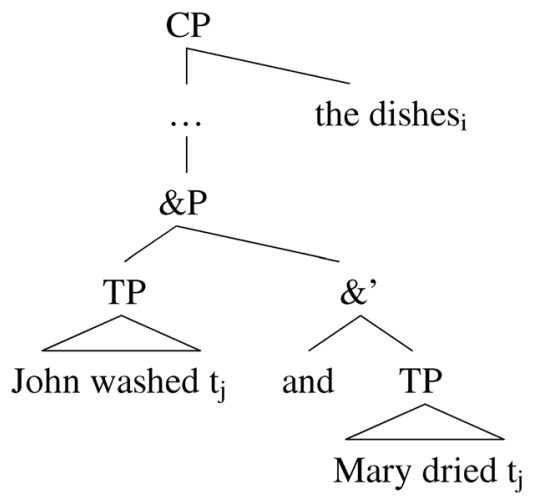

Others propose that the pivot occupies its canonical position and is thus not moved. There are three versions of the in-situ approach to RNR. According to the Parallel Merge approach (McCawley 1982, 1988; Wilder 1999; Phillips 2003; Abels 2004; Bachrach and Katzir 2007; among others), the pivot is in-situ in all the conjuncts of the coordination, as it is shared by both conjuncts as a result of Parallel 
Merge (4a). In the ellipsis analysis (Chae 1991; Sohn 2001; Chalcraft 2006; Ha 2008, 2009; Wexler and Culicover 1980; Kayne 1994; Hartmann 2000; Bošković 2004; An 2008; among others), the pivot is in-situ in the final conjunct, and the gap in the non-final conjunct(s) results from ellipsis or PF-deletion (4b).

(4)

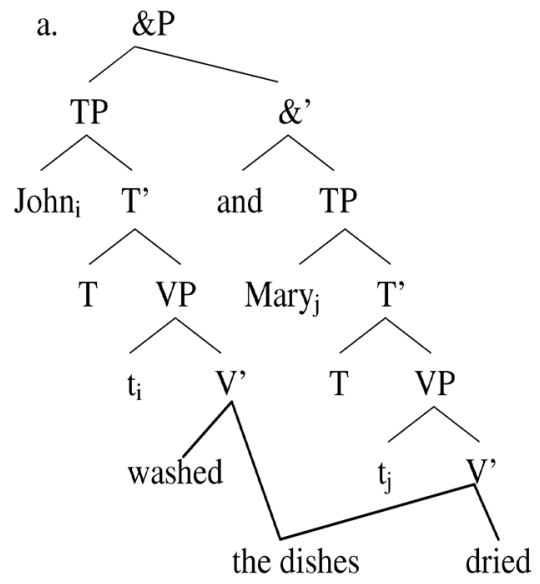

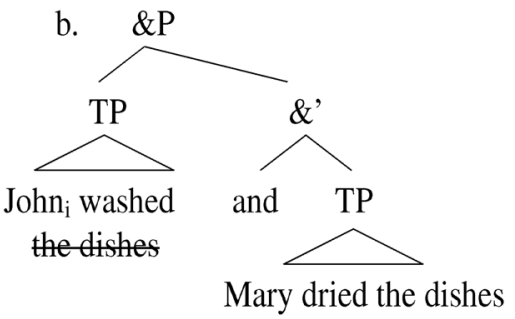

Peterson (1999) proposes that RNR is not a case of true coordination, and that the non-final conjunct is not syntactically related to the host clause but a parenthetical which features ellipsis of material which is supplied by the host clause. The representation of (1) would thus be as in (5). Peterson does not specify whether the ellipsis site in the parenthetical results from PF-deletion or whether it is occupied by a null pronominal. With the dotted line, Peterson intends to indicate that the parenthetical is semantically but not syntactically related to the host. Although in both (4b) and (5) involve an in-situ pivot and ellipsis, the crucial difference is that in the former the pivot is in-situ in the second conjunct and ellipsis applies to the first conjunct, whereas in the latter the pivot is in-situ in the first conjunct and ellipsis applies to the second conjunct.

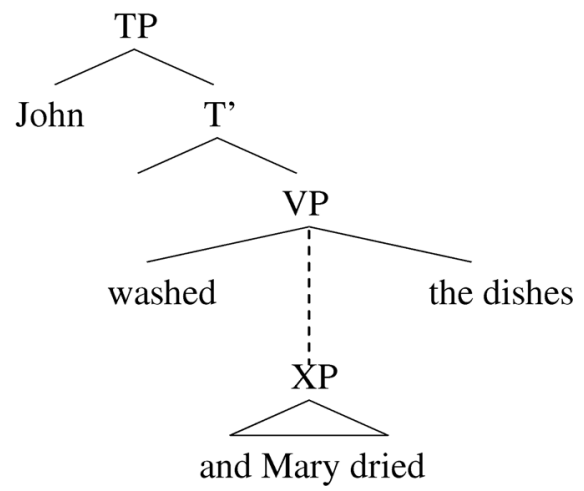


Both the ex-situ and the in-situ pivot approach have problems when trying to provide empirical coverage for RNR facts. There are a number of facts which strongly support the ex-situ pivot approach to RNR, whereas other data clearly militate in favour of an in-situ pivot analysis.

The facts in (6)-(8) can only be explained if the pivot has moved and is thus ex-situ. In (6) we see that the pivot can appear to the right of material which modifies both conjuncts of the coordination and must thus sit in some position outside the second conjunct: were the pivot all of his old manuscripts in-situ, it would not follow the PP on the same day.

(6) Joss will [sell all of his old manuscripts. to a shelter] on the same day, [Sabbagh (2007: 356)]

Also very hard to explain for the in-situ approach are the scope facts from Sabbagh (2007) illustrated in (7). In the RNR example (7a), the universally quantified pivot can take scope over the existentially quantified subject, whereas it cannot in its non-RNR counterpart (7b). Assuming that LF Quantifier Raising is clause-bound, this shows that the pivot every patient who was admitted last night has overtly ATB-moved to a position that c-commands the existentially quantified subject some nurse in (7a).

(7) a. Some nurse gave a flu shot to , and administered a blood test for every patient who was admitted last night. $\forall>\exists, \exists>\forall$

b. Some nurse gave a flu shot to every patient, and administered a blood test for every patient.

$* \forall>\exists, \exists>\forall$

[Sabbagh (2007: 365)]

The licensing of parasitic gaps, whose occurrence crucially depends on the presence of a variable resulting from an A'-movement operation, is also supportive of the ex-situ pivot analysis: as Postal (1994) notices, parasitic gaps are licensed in RNR (8), in clear parallelism with wh-ATB-movement (9) (examples from Valmala 2012:10):

(8) a. Peter reviewed without reading $[e]_{\mathrm{PG}}$, and Bill revised, two papers on RNR.

b. Peter revised, and Bill reviewed without reading $[e]_{\mathrm{PG}}$, two papers on RNR.

c. Peter edited without revising $[e]_{\mathrm{PG}}$, and Bill reviewed without reading $[e]$ PG, two papers on RNR.

1. Postal (1994) calls them pseudo-parasitic gaps because for him they involve ATB-movement, not a null operator. In any case, what is important for present purposes is that these (pseudo-)parasitic gaps must also be licensed by a non-c-commanding variable. See Hornstein and Nunes (2002) for an analysis in which parasitic gaps and ATB-movement involve the same syntactic operation, that he calls sideward movement, in the general case. 
(9) a. Which papers did Peter file without reading $[e]_{\mathrm{PG}}$ and Bill read twice?

b. Which papers did Peter read twice and Bill file without reading $[e]_{\mathrm{PG}}$ ?

c. Which papers did Peter edit without revising $[e]_{\mathrm{PG}}$ and Bill review without reading $[e]_{\mathrm{PG}}$.

The facts in (10)-(12), on the contrary, can only be explained if the pivot is in-situ. One argument comes from the fact that RNR does not obey locality conditions that constrain movement in the general case: (10a) illustrates island insensitivity, and (10b) illustrates insensitivity to the Right Roof Condition. The second fact that is clearly incompatible with an ex-situ pivot analysis of RNR is that parts of words, which cannot undergo syntactic movement, can be pivots (11).

(10) a. John knows [someone who buys _ ], and Jamie knows [someone who sells ], pictures of Fred.

[Sabbagh (2007: 382)]

b. Josh promised that he would give _ to Jamie, and Joss claimed that he was going to give _ to Sue, all of the answers to the final exam. [Sabbagh (2007: 351)]

(11) [Your theory under-__], and [my theory over-_ ] generates.

[Sabbagh (2007: 390)]

Also incompatible with an ex-situ pivot analysis is the fact that the pivot can appear in positions which are clearly internal to the second conjunct: as shown in (12), to Mary, which can only be interpreted as an argument of the second conjunct, follows the pivot the book.

(12) John should fetch and give the book to Mary.

[Wilder (1999: 11)]

So the situation is that neither the ex-situ nor the in-situ analyses are able to account for all the RNR facts. In this context, Valmala (2012) observes that there is disagreement in the existing literature on the construction not only with respect to its structural representation but also with respect to its written representation, its prosodic properties, and its focal properties.

Concerning the written representation of RNR structures, they have been represented in the following ways: (i) with two commas, one between each conjunct and one between the pivot and the preceding material (13a); (ii) with a comma between the pivot and the preceding material (13b); (iii) with a comma between the first and the second conjunct (13c); and (iv) without commas (13d). Scholars often alternate either between the patterns in (13a) and (13b) or between those in (13c) and (13d); (13a) and (13d) being the most common ones. The two basic patterns for the written representation of RNR are thus characterized by the presence (14b) or absence (14a) of a comma between the pivot and the preceding material, the comma between the two conjuncts being optional. The pair in (15) exemplifies both patters. 
(13) a. Syntax students like, or at least barely tolerate, $4 \mathrm{~h}$ exams.

[Cann et al. (2005: 504)]

b. John bought and Sally sold, some books.

[Barros and Vicente (2010: 1)]

c. Bill made, and John sold a piece of furniture.

[Ha (2008: 1)]

d. Everyone admired but nobody venerated the master. [Selkirk (2002: 2)]

(14) a. conjunct 1 (comma) conjunct 2 - pivot

b. conjunct 1 (comma) conjunct 2 comma pivot

(15) a. John likes(,) and Bill hates that picture of Mary.

b. John likes(,) and Bill hates, that picture of Mary.

Valmala (2012) notices that, because commas are typically used to mark prosodic breaks, it might be the case that (14a) and (14b) actually represent two different prosodic patterns: one with a prosodic break preceding the pivot (14b), and one without such a prosodic break (14a).

Actually, many of the authors who use the representation in (14b) (Hudson 1976; Chae 1991; Sabbagh 2007; among others) consider that the presence of an intonation break between the pivot and the preceding material is one of the characteristic properties of RNR:

«... one characteristic of the construction is that there is a marked intonation break before the 'raised' element»

[Hudson (1976: 549)]

«... the special prosody on the factor (an intonation break before the factor) acts as a cue for indicating that the factor is exactly the element which is missing.»

[Chae (1991: 53)]

«... there is no direct word order evidence for the displacement, although there is an intonation pause, which can be plausibly be taken to indicate the separation of the right-node-raised element from ...»

[Sabbagh (2007: 352)]

In the written representation in (14a) used by other authors, however, nothing indicates the presence of a prosodic break immediately before the pivot. As the presence vs. absence of prosodic breaks is often taken to be the manifestation of different syntactic structures, the question that emerges is whether (14a) and (14b) are or not instances of one single syntactic structure.

Valmala (2012) observes that there is disagreement in the literature also concerning the focal properties of RNR. For Hartmann (2000) the constituent preceding the pivot must be contrastive focus. Abe and Hornstein (2012), on the contrary, suggest that the pivot itself is focus. For Selkirk (2002), the constituents preceding both the gap in the first conjunct and the pivot in the second conjunct are contras- 
tive focus, whereas the pivot is presentational focus. Bošković (2004: 14) claims that «the shared constituent in RNR receives a strong non-contrastive focus, and the coordinated phrases receive contrastive focus».

Valmala proposes that there are two different information-structural and focal patterns in RNR, illustrated in (17B) and (18B) below. In (16B), all the material preceding the pivot, which has been introduced in (16A), is clearly part of the presupposition and thus not focal, and the pivot itself is (contrastive) focus, here identified by capitalization. This pattern of RNR, that Valmala calls Focal-Pivot RNR (hereafter FP-RNR), is typically preceded by an intonation break and is represented with a comma in writing.

(16) A: It seems that Susan accepted Bill's paper on RNR and John rejected it.

B: No. Susan accepted __ and John rejected __, MY paper on RNR, (not Bill's). [Valmala (2012: 16)]

In (17B), on the contrary, the DPs John, Peter, and that picture of Mary are part of the presupposition and thus not focal, and the verb hates before the gap in the first conjunct and the verb likes before the pivot in the second conjunct are non-presupposed and thus focal. Capitalization again identifies the foci. In this pattern of RNR, like in the non-RNR reply in (18B), there is no prosodic break before the pivot. There are cases of RNR like (19a) in which neither the pivot the driver nor other constituents of the first or the second conjunct can be identified as focal. Here a prosodic break is also impossible (19b). What (17B) and (19a) have in common is that the pivot is not focal. This pattern is dubbed Non-Focal Pivot RNR (henceforth NFP-RNR).

(17) A: What do John and Peter think of that picture of Mary?

B: John HATES _ but Peter LIKES that picture of Mary.

[adapted from Erteschik-Shir (2010: slide 14)]

(18) A: What do John and Peter think of that picture of Mary?

B: They HATE that picture of Mary.

(19) a. Do not speak to or distract the attention of the driver while the bus is moving.

b. *Do not speak to or distract the attention of, the driver while the bus is moving.

The pair in (20) illustrates the distinction. In the FP-RNR (20a) the pivot is focus and is preceded by an intonation break, whereas in NFP-RNR the pivot is not focal and is not preceded by an intonation break.

(20) a. John likes and Bill hates, THAT PICTURE OF MARY.

b. John likes and Bill HATES that picture of Mary. 
With the conclusion that RNR is not a uniform phenomenon as regards its focal and prosodic properties, the obvious question is whether FP-RNR and NFP-RNR involve identical syntactic derivation or not. Valmala argues that the answer is negative. He provides a number of arguments supporting that FP-RNR involves movement of the pivot whereas NFP-RNR does not. Below I reproduce two of those arguments.

FP-RNR and NFP-RNR behave differently concerning the possibility of licensing parasitic gaps. Let us go back to the examples provided in (8), repeated here as (21), which called for an ex-situ pivot analysis. Notice that these, as indicated by the focal nature of the pivot and the prosodic break preceding it, are instances of FP-RNR. NFP-RNR, on the contrary, does not license parasitic gaps (22b-d), which indicates that the pivot is in-situ and the conditions for licensing of parasitic gaps are thus not satisfied.

(21) a. Peter reviewed without reading $[e]_{\mathrm{PG}}$, and Bill revised, TWO PAPERS ON RNR.

b. Peter revised, and Bill reviewed without reading $[e]_{\mathrm{PG}}$, TWO PAPERS ON RNR.

c. Peter edited without revising $[e]_{\mathrm{PG}}$, and Bill reviewed without reading $[e]$ PG, TWO PAPERS ON RNR.

(22) a. Peter reviewed and Bill REVISED my papers.

b. *Peter REVIEWED without reading $[e]_{\mathrm{PG}}$ and Bill REVISED my paper.

c. *Peter PUBLISHED and Bill REVIEWED my paper without reading $[e]_{\mathrm{PG}}$.

d. *Peter PUBLISHED and Bill REVIEWED without reading $[e]_{\mathrm{PG}}$ my paper.

Complements of prepositions that cannot be left stranded by (leftward) movement (23) can be pivots in NFP-RNR (24a,c) but not in FP-RNR (24b,d), which again is readily explained if the pivot is in-situ in the former and ex-situ in the latter.

(23) a. *Which building is he inside?

b. *Which bridge did his car stop under?

(24) a. John is outside and Bill is INSIDE the black building.

b. *John is outside, and Bill is inside, THE BLACK BUILDING.

c. His car stopped ON and mine stopped UNDER the blue bridge.

d. *His car stopped on, and mine stopped under, THE BLUE BRIDGE.

The conclusion is thus that both the in-situ and the ex-situ approach to English RNR are partially right, and that there is a clear division of labour between the competing analyses of the phenomenon, so that the rightward ATB-movement 
analysis is a possible solution only for FP-RNR, and the in-situ PF-deletion/ellipsis and multidominance analyses can only be considered for NFP-RNR. ${ }^{2}$ It also implies that the relevant question when considering crosslinguistic variation in the availability of RNR is no longer whether a given language has RNR or not, but what type of RNR it has, if any, and what type of syntactic derivation it involves.

\section{2. (FP and NFP)-RNR in Catalan and Spanish}

RNR has received very little attention in the literature on Catalan and Spanish (C\&S hereafter). To the best of my knowledge, Catalan RNR has never been analyzed, and Camacho (2003), who considers RNR not to be very natural in Spanish, constitutes the only reference to the construction in the literature on Spanish. ${ }^{3} \mathrm{He}$ provides the examples in (25) when providing evidence that propositional adverbs like siempre 'always' do not modify simplex DPs in Spanish.

(25) a. ?Los niños traen $e_{i}$, y entregan siempre, [un regalo] $]_{\mathrm{i}}$. the children bring and deliver always a present 'The children bring, and always deliver, a present.'

b. *Los niños traen $e_{i}, \mathrm{y}$ entregan, [siempre un regalo] $]_{\mathrm{i}}$. the children bring and deliver always a gift

[Camacho (2003: 25-26)]

On the basis of the contrast between (25) and (26), Camacho argues in support of an in-situ approach to (Spanish) RNR. These examples show that when the pivot

2. See Sabbagh (2007) and Abe and Hornstein (2012) for ATB-movement approaches to (FP-)RNR that provide accounts of the lack of locality effects.

3. This is not exactly so. Florez (1985) provides (i) as an example of Spanish RNR. It is indeed the case that (i) superficially has the property which is typical of RNR: the DP los cuadros de Picasso 'Picasso's paintings' is omitted in absolute final position of the non-final conjunct of a coordination. However, examples like (i) should not be considered when analyzing the availability and properties of FP-RNR in Spanish, as the gap can also occur in the second conjunct of a coordination (ii), or in non-coordination (iiiB). The elliptical subject in the first conjunct of (ii) and in (iiiB) is clearly an instance of subject pro-drop, and there is no reason to argue against an identical analysis for (i).

(i) A María le gustan _, y Juan daría cualquier cosa por comprar los cuadros to María DAT like.3PL and Juan give.COND anything for buy the paintings de Picasso.

of Picasso

'María likes and Juan would give anything to buy Picasso's paintings.'

[Florez (1985: 309, fn. 1); glosses and translation mine]

(ii) Juan daría cualquier cosa por comprar los cuadros de Picasso, y a María Juan give.Cond anything for buy the paintings of Picasso and to María simplemente le gustan. simply DAT like.3PL 'Juan would give anything to buy Picasso's paintings, and María simply likes them.'

(iii) Speaker A: Juan daría cualquier cosa por comprar los cuadros de Picasso. Speaker B: A María también le gustan. 
is a PP complement of verbs with different selectional restrictions in each conjunct, it is the selectional restrictions of the verb of the second conjunct that must be satisfied. In (26a) and (27a), the verbs fue 'went' and vino 'came' select PPs headed by the prepositions $a$ 'to' and de 'of' respectively, but the PP pivot can be introduced by de only if the second verb selects for that preposition. (26b) and (27b) illustrate the same point with the verbs disparar 'shoot', which selects a PP introduced by contra 'against', and amedrentar 'harass', which selects a PP introduced by $a$ 'to'. Within an ATB-movement analysis of RNR, he concludes, it is not clear why order should matter (examples from Camacho 2003: 158):

(26) a. Desde aquel día fue y vino del Instituto. from that day went and came of-the Institute 'From that day he/she went and came from the institute.'

b. Primero amedrentaron y luego dispararon contra los manifestantes. first harassed and then shot against the demonstrators 'First they harassed, and then they shot at the demonstrators.'

(27) a. *Desde aquel día vino y fue del Instituto. from that day came and went of-the Institute

b. *Dispararon y amedrentaron contra los manifestantes. shot and harassed against the demonstrators

I will later come back to Camacho's examples, but notice for the moment that he represents the RNR examples in (25) with a comma before the pivot, whereas in (26)-(27) there is no comma before the pivot. This makes me suspect that the examples in (25) are cases of FP-RNR in which the pivot is ex-situ, whereas in (26)-(27) we are dealing with examples of NFP-RNR in which the pivot is in-situ.

\subsection{Catalan and Spanish have both FP-RNR and NFP-RNR}

As regards prosodic and information-structural/focal properties, $\mathrm{C} \& \mathrm{~S}$ have both FP and NFP-RNR. Consider the examples in (28). These examples feature the two properties that characterize FP-RNR: a prosodic break before the pivot and a non-presupposed focal interpretation of the pivot (unless otherwise specified, the Catalan examples come first):

(28) a. En Joan va llegir, i en Lluís va arxivar, gairebé tots els the Joan AUX read and the Lluís AUX file almost all the teus articles sobre RNR. your papers on RNR

b. Joan leyó, y Lluís archivó, casi todos tus artículos sobre RNR. Joan read and Lluís filed almost all your papers on RNR 'Joan read, and Lluís filed, almost all your papers on RNR.' 
The examples in (29), on the contrary, are clear instances of NFP-RNR: the focus is not on the pivot lluç/merluza 'hake' but on material preceding the gap and the pivot in each conjunct (the wh-phrases or the verbs arrebossar/empanó 'bread/ breaded' and fregir/frió 'fry/fried'), and there is no prosodic break before the pivot in the same way in which there is no prosodic break between the object and the preceding material in the non-RNR examples in (30). That these are examples of RNR and not some other phenomenon is evidenced by the fact that the gap cannot appear in the second conjunct (31)-(32).

(29) a. M'agradaria saber qui va arrebossar i qui va fregir el me+like.COND know who AUX bread and who AUX fry the lluç.

hake

b. Me gustaría saber quién empanó y quién frió la merluza. me like.COND know who breaded and who fried the hake 'I would like to know who breaded and who fried the hake.'

(30) a. M'agradaria saber qui va fregir el lluç.

b. Me gustaría saber quién frió la merluza.

(31) a. *En Joan va llegir gairebé tots els teus articles sobre RNR, i en Lluís va arxivar.

b. *Juan leyó casi todos tus artículos sobre RNR, y Luis archivó.

(32) a. *En Joan va arrebossar el lluç i en Lluís va fregir.

b. *Juan empanó la merluza y Luis frió.

With the conclusion that C\&S have both FP and NFP-RNR, the obvious question that emerges is what their syntactic derivation is. I concentrate on this issue in the sections that follow.

\subsection{Catalan and Spanish FP-RNR involves ATB-movement}

I will consider two alternatives for the derivation of C\&S FP-RNR: the ex-situ ATBmovement approach and Peterson's (1999) parenthetical analysis. The reason for doing so is that, although in Peterson's analysis the pivot is in-situ, the RNR pattern that he is trying to account for is FP-RNR, as evidenced by the quotation below concerning the prosodic properties of the phenomenon. He is obviously not trying to characterize NFP-RNR, which has none of the intonation properties of parentheticals.

«... these are shown to be interpolations by the marked parenthetical nature of their intonation contours.»

[Peterson (1999: 242)] 
In the discussion of English FP-RNR in section 1, I provided arguments that FP-RNR involves ATB-movement but did not discuss the parenthetical analysis. Here I will consider the applicability of Peterson's proposal concerning the representation of FP-RNR to English and C\&S, showing that it cannot involve a parenthetical and providing arguments that, in $\mathrm{C} \& \mathrm{~S}$, like in English, FP-RNR involves ATB-movement of the pivot.

Let us first consider the parenthetical analysis proposed in Peterson (1999) represented in (5) above that I reproduce below as (33). Remember that with the dotted line he intends to indicate that the second conjunct in FP-RNR is semantically but not syntactically attached to the host.

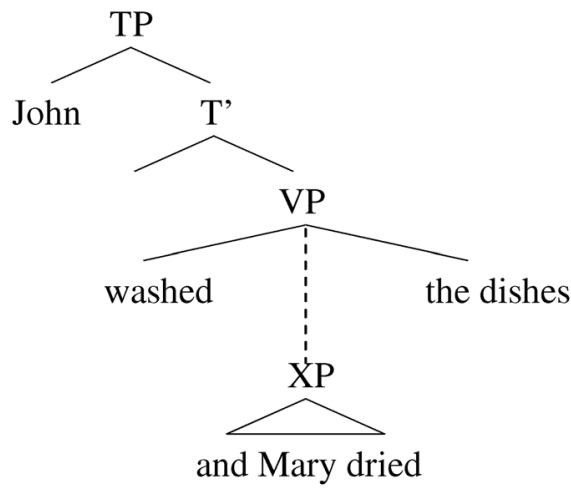

There are a number of arguments against treating FP-RNR as involving a parenthetical non-syntagmatic relation. Peterson claims that a typical property of nonsyntagmatic relations is that juxtaposed elements are 'moveable', so that they can often appear as parentheticals (34a), and as peripherals (34b,c).

(34) a. John Smith, would you believe, is asking to see you.

b. Would you believe, John Smith is asking to see you.

c. John Smith is asking to see you, would you believe.

[Peterson (1999: 238)]

But then, if the second conjunct in FP-RNR is a non-syntagmatic relation, we would expect it to be able to appear as a 'peripheral' in final position. This is clearly not the case: the impossibility of (31), repeated here as (35), is precisely what any sensible theory of RNR must explain.

(35) a. *En Joan va llegir gairebé tots els teus articles sobre RNR, i en Lluís va arxivar.

b. *Juan leyó casi todos tus artículos sobre RNR, y Luis archivó. 
Peterson also shows that a property of non-syntagmatic relations is that the juxtaposed clause can have independent illocutionary force, as shown in (34) above where the juxtaposed clause has interrogative illocutionary force although the host clause is a declarative. We would thus expect the 'interrupting' clause in RNR to also be able to have independent illocutionary force. This is impossible both in English (36) and C\&S (37) FP-RNR.

(36) *John bought, but why didn’t you buy, those mystery novels.

(37) a. *En Joan va comprar, però per què no vas comprar tu, aquestes the Joan AUX buy but why not AUX buy you these novel-les de misteri. novels of mystery

b. *Juan compró, pero por qué no compraste tú, esas novelas de Juan bought but why not bought.2sG you those novels of misterio.

mystery

Let us now consider the predictions that the parenthetical analysis makes concerning the interpretation of FP-RNR structures in embedded clauses. There is ample evidence that parentheticals are not within the scope of their host clause. The following facts from de Vries (2012) illustrate this point. In (38a) the subject of the parenthetical cannot have a bound pronoun reading, and the R-expression in the parenthetical in (38b) does not induce principle $\mathrm{C}$ violation effect with the intended interpretation. These facts indicate that the subject of the host clause does not have the parenthetical within its c-command domain. I add (39), where the bound reading for the subject pronoun of the parenthetical is impossible, in order to show that the parenthetical is outside the scope of the matrix clause in contexts of embedding.

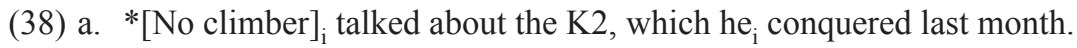

b. $\mathrm{He}_{\mathrm{i}}$ said -this is typical for Joop $\mathrm{i}_{\mathrm{i}}$ - that he $\mathrm{i}_{\mathrm{i}}$ didn't like veggie burgers.

[de Vries (2012: 155)]

(39) $*[\text { No climber }]_{\mathrm{i}}$ said that I talked about the $\mathrm{K} 2$, which he $\mathrm{i}_{\mathrm{i}}$ conquered last month.

If RNR involves a parenthetical not syntactically related to the host, we would expect sentences like (40) below to have an interpretation akin to (41), i.e. the 'parenthetical' should not be within the scope of the matrix verb. This is clearly not the case: the interpretation of (40) is one in which the second conjunct of the coordination is obligatorily within the scope of the matrix verb. 
(40) a. Jo crec que en Joan llegirà, però en Lluís ignorarà, gairebé I think that the Joan read.FuT but the Lluís ignore.FUT almost tots els teus articles.

all the your papers

b. Yo creo que Joan leerá, pero Lluís ignorará, casi todos tus I think that Joan read.FUT but Lluís ignore.FUT almost all your artículos.

papers

'I think that Joan will read, but Lluís will ignore, almost all your papers.

(41) a. Jo crec que en Joan llegirà gairebé tots els teus articles, però I think that the Joan read.FUT almost all the your papers but en Lluís els ignorarà.

theLluís them ignore.FuT

b. Yo creo que Joan leerá casi todos tus artículos, pero Lluís I think that Joan read.FUT almost all your papers but Lluís los ignorará.

them ignore.FUT

'I think that Joan will read almost all your papers, but Lluís will ignore them.'

These facts thus clearly show that Peterson's claim that the non-final conjunct in FP-RNR is a parenthetical which is not syntactically related to the host cannot be correct.

An anonymous reviewer suggests that the (lack of) scope facts illustrated in (40) are not enough to rule out a parenthetical approach to FP-RNR and crucially depend on one's analysis of parentheticals in the general case. Specifically, the reviewer suggests that if the second clause is a 'parenthetical' adjoined to the embedded CP, the interpretation of the data in (40) would be accounted for. If this alternative is correct, the representation of (40) should be as in (42). If the second conjunct or 'parenthetical' is attached to the embedded CP, the pivot, which linearly follows the 'parenthetical', must have undergone movement to a higher (CP-adjoined) position. As the reviewer correctly notes, the scope facts in (40) would be captured, as in (42) the matrix verb c-commands the 'parenthetical'. ${ }^{4}$

4. See also Altshuler and Déprez (2007) for a proposal that certain parentheticals are syntactically related to the host that I do not discuss here both because they deal with a topic construction that has properties fundamentally different from those of FP-RNR and because for it to work verbs in Spanish must remain inside VP (Altshuler and Déprez 2007: 11). 


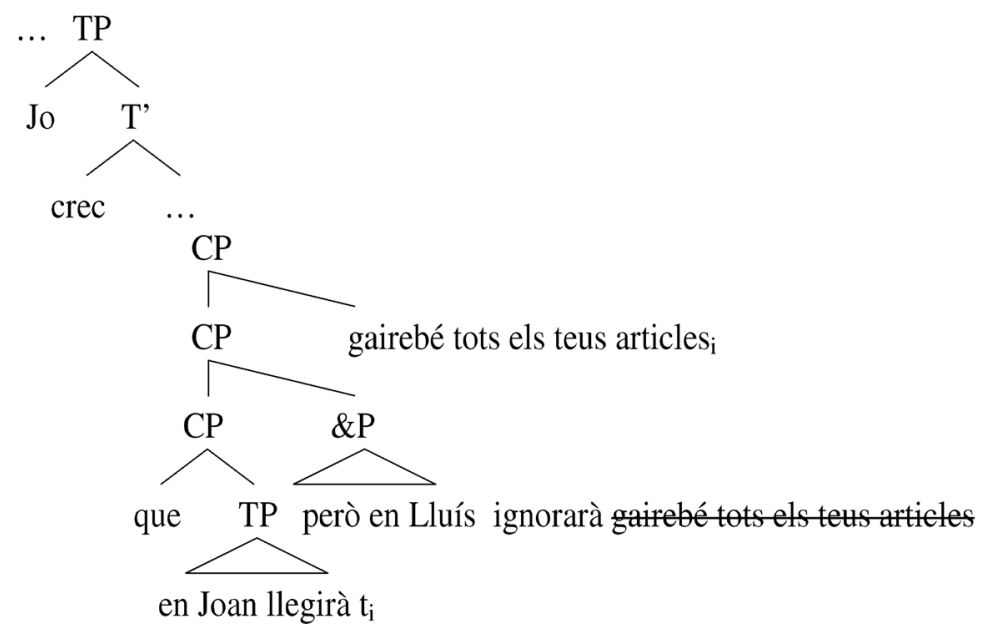

There are two problems with this approach. The first is conceptual in nature: because this proposal clearly cannot be extended to bona fide parentheticals -as the facts in (38) and (39) show-, one would be forced to assume the existence of two totally different 'parenthetical' structure-building mechanisms. The second problem is empirical: it wrongly predicts that (43), which would be the result of having the object of the host clause either in-situ or moved to an adjoined position lower than the CP-adjoined position of the 'parenthetical', should be good. In order to rule it out we should stipulate that the 'parenthetical' can be adjoined to CP only if the object of the host clause undergoes movement to a higher position.

(43) a. *Jo crec que en Joan llegirà, gairebé tots els teus articles sobre I think that the Joan read.FUT almost all the your papers on RNR, però en Lluís ignorarà.

RNR but the Lluís ignore.FUT

b. *Yo creo que Joan leerá casi todos tus artículos sobre RNR, I think that Joan read.FuT almost all your papers on RNR pero Lluís ignorará.

but Lluís ignore.FUT

Now the obvious question is whether Peterson's analysis can be reinterpreted so that FP-RNR involves a case of ordinary coordination in which there is ellipsis in the second conjunct with movement of the pivot from the first conjunct to a $\mathrm{CP}$-adjoined position. In that case the derivation of (28a), repeated here as (44a), would be as in (44b). 
(44) a. En Joan va llegir, i en Lluís va arxivar, gairebé tots els teus articles sobre RNR.

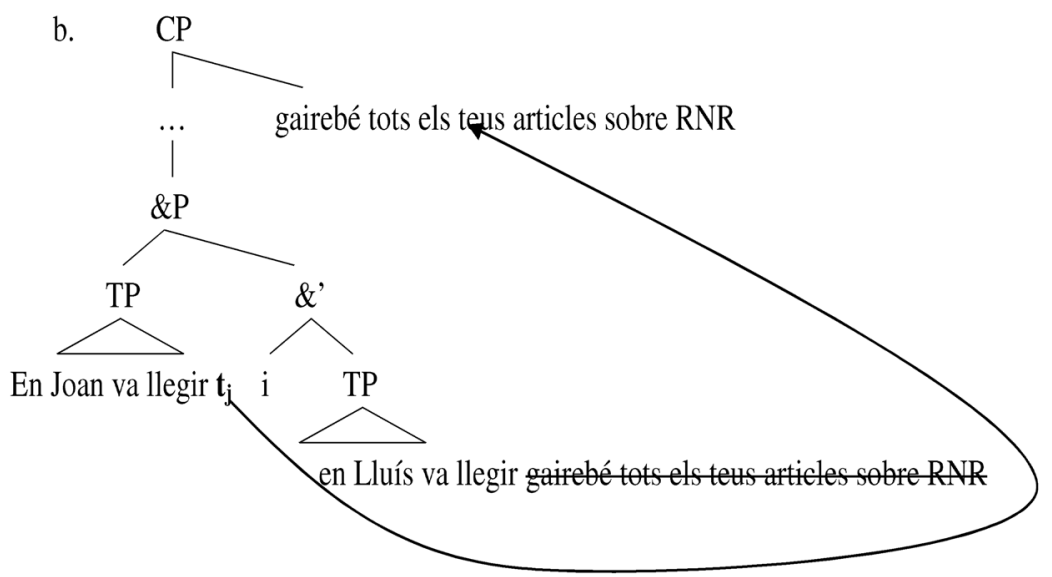

The obvious problem with this derivation is that the movement of the pivot violates the Coordinate Structure Constraint (CSC). Additionally, we should explain why ellipsis of the object in the second conjunct is obligatory, as shown in the examples in (45) which contrast with (46).

(45) a. *En Joan va comprar(,) i en Lluís va llegir tres llibres the Joan AUX buy and the Lluís AUX read three books (també), tres llibres. too three books

b. *Juan compró(,) y Luís leyó tres libros (también), tres libros. Juan read and Luis read three books too three books

(46) a. En Joan va comprar tres llibres i en Lluís va llegir tres llibres.

b. Juan compró tres libros, y Luis leyó tres libros.

In order to circumvent the problem of the CSC violation, one could appeal to the representational approach to the CSC developed in Fox (2000), among others. For Fox, the CSC is not a derivational condition but a representational condition on LF representations. Within this approach, the contrast in (47) is straightforwardly explained: in (47b) there is no violation of the CSC because the in-situ operator moves at $\mathrm{LF}$ and binds a variable in both conjuncts.

(47) a. *Which student likes which professor and hates the Dean?

b. Which student likes which professor ${ }_{\mathrm{i}}$ and wants him $_{\mathrm{i}}$ to be on his committee? 
Assuming this type of approach to the CSC, one could argue that the missing object in the second conjunct in the representation in (44) is occupied by the null object which is coreferential with the pivot (48), a derivation equivalent to that proposed in Zhang (2004) for leftward ATB-movement. The first problem for this solution is that the languages under discussion do not have null objects in the general case, so an explanation should be provided for why they are only licensed here, and the second problem is that we would expect the overt counterpart of the null pronominal to be able to show up, contrary to fact (49). ${ }^{5}$

(48) a. En Joan va comprar $t_{i}$, $i$ en Lluís va llegir pro, tres llibres the Joan AUX buy and the Lluís AUX read three books sobre $\mathrm{RNR}_{\mathrm{i}}$.

on RNR

b. Joan compró $\mathrm{t}_{\mathrm{i}}, \mathrm{y}$ Lluís leyó pro ${ }_{i}$, tres libros sobre $\mathrm{RNR}_{\mathrm{i}}$. Joan bought and Lluís read.PAST three books on RNR 'Joan bought, and Lluís read, three books on RNR.'

(49) a. *En Joan va comprar $\mathrm{t}_{\mathrm{i}}, \mathrm{i}$ en Lluís els va llegir, tres llibres the Joan AUX buy and the Lluís them AUX read three books sobre $\mathrm{RNR}_{\mathrm{i}}$.

on RNR

b. *Juan compró $\mathrm{t}_{\mathrm{i}}, \mathrm{y}$ Luis $\operatorname{los}_{\mathrm{i}}$ leyó, tres libros sobre $\mathrm{RNR}_{\mathrm{i}}$. Juan bought and Luis them read.PAST three books on RNR

The conclusion is thus that FP-RNR cannot involve movement of the pivot from the first conjunct with ellipsis or a null pronominal in the second conjunct. Now I turn to the ATB-movement analysis of C\&S FP-RNR.

My first argument in support of an ATB-movement analysis for C\&S FP-RNR comes from parasitic gap licensing. Like in English, C\&S FP-RNR licenses parasitic gaps in the first conjunct (50), in the second conjunct (51), and in both (52). The structure of (52a) is given in (53) below. Notice that the licensing of parasitic gaps also strongly militates against the parenthetical approach in (33), where there are no variables that could license them. ${ }^{6}$

5. Even if we assumed that the missing object of verbs like vender 'sell' and comer 'eat' is pro, the RNR structures considered are not lexically restricted, and although it is true that some varieties of Spanish like Basque Spanish allow null objects, RNR is not restricted to those speakers. An anonymous reviewer suggests that the representations in (48)-(49) would be correct if null objects are licensed in C\&S only in those configurations in which there is an antecedent. The problem with this alternative is that it predicts the configurations in (31)-(32) in the text to be good, as they also contain an antecedent for the null object.

6. There are speakers who do not like (50)-(52) due to the fact that they dislike parasitic gaps in the general case. What is important for present purposes is that the speakers who accept parasitic gaps like them in FP-RNR contexts. 
(50) a. En Joan va llegir sense entendre $[e]_{\mathrm{PG}}$, i en Pere va ignorar, the Joan AUX read without understand and the Pere AUX ignore tots els teus articles sobre RNR.

all the your papers on RNR.

b. Joan leyó sin entender $[e]_{\mathrm{PG}_{\mathrm{G}}}, \mathrm{y}$ Pere ignoró, todos tus Joan read without understand and Pere ignored all your artículos sobre RNR.

papers on RNR

'Joan read without understanding, and Pere ignored, all your papers on RNR.'

(51) a. En Joan va ignorar, i en Pere va llegir sense entendre $[e]_{\mathrm{PG}}$, tots els teus articles sobre RNR.

b. Joan ignoró, y Pere leyó sin entender $[e]_{\mathrm{PG}}$, todos tus artículos sobre RNR.

(52) a. En Joan va llegir sense entendre $[e]_{\mathrm{PG}}$, i en Pere va arxivar the Joan AUX read without understand and the Pere AUX file sense llegir $[e]_{\mathrm{PG}}$, tots els teus articles sobre RNR. without read all the your papers on RNR

b. Joan leyó sin entender $[e]_{\mathrm{PG}}, \mathrm{y}$ Pere archivó sin leer $[e]_{\mathrm{PG}}$, Joan read without understand and Pere filed without read todos tus artículos sobre RNR.

all your papers on RNR

'Joan read without understanding, and Pere filed without reading, all your papers on RNR.'

(53)

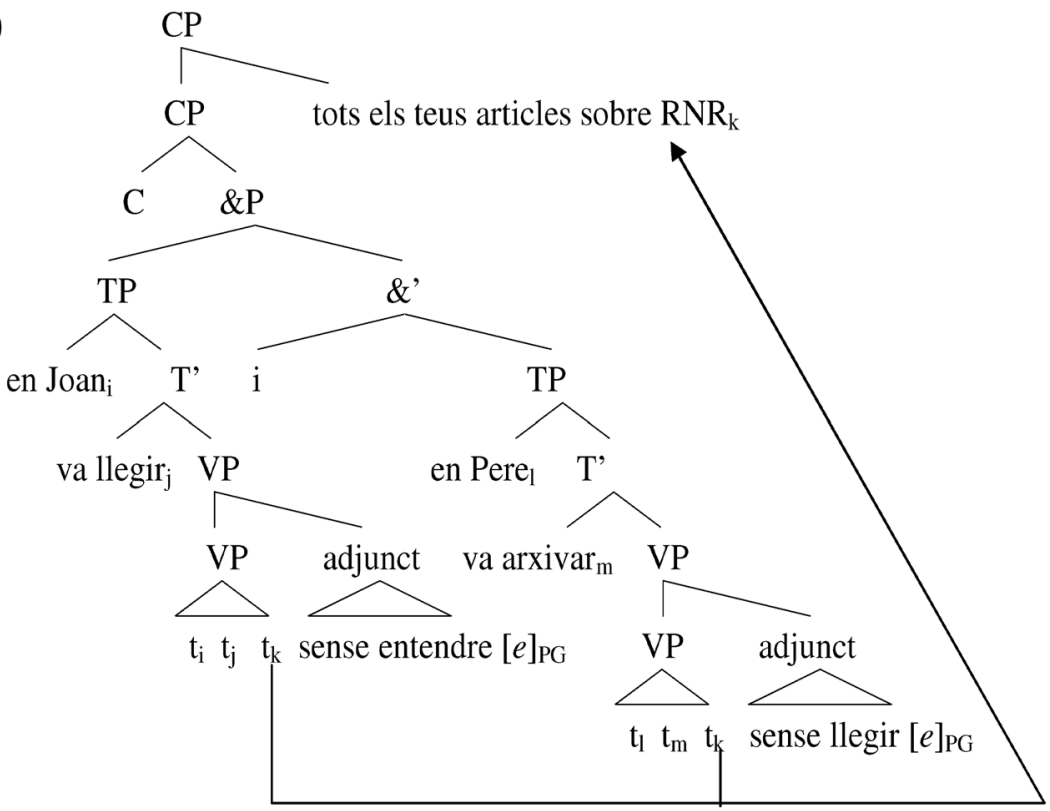


Ellipsis facts also indicate that the pivot is ex-situ in C\&S FP-RNR. Let us assume that the ellipsis phenomenon that typically occurs in contexts of polarity agreement/disagreement illustrated in (54) involves deletion/non-pronunciation of the TP in the PF component (examples from Catalan; the same applies to Spanish):

(54) En Joan llegirà tots els teus articles sobre RNR i jo probablement the Joan read.FUT all the your papers on RNR and I probably també $\left[_{\mathrm{TP}} e\right]$.

too

'Joan will read all your papers on RNR, and I probably will too.'

Consider now the predictions that emerge from the interaction between FP-RNR and TP ellipsis. If the pivot is in-situ in FP-RNR, TP ellipsis is expected to be impossible for the simple reason that, as in (54) above, eliminating the TP will also inevitably eliminate the object, which is contained in the TP. On the contrary, if the pivot evacuates the TP before PF as a result of ATB-movement, FP-RNR and TP ellipsis are expected to be able to co-occur. As shown in (55) and (56), FP-RNR can interact with TP-ellipsis. The tree in (57) illustrates the detailed derivation of (55).

(55) L'Anna llegirà, i jo probablement també, gairebé tots els teus the+Anna read.FUT and I probably too almost all the your articles sobre RNR.

papers on RNR

'Anna will read, and I probably will too, almost all your papers on RNR.'

(56) En Joan va llegir, i és possible/probable que en Miquel també, the Joan AUX read and is possible probable that the Miquel too gairebé tots els teus articles sobre RNR. almost all the your papers on RNR 'Joan read, and it might be the case that Miquel did too, all you papers on RNR.' 


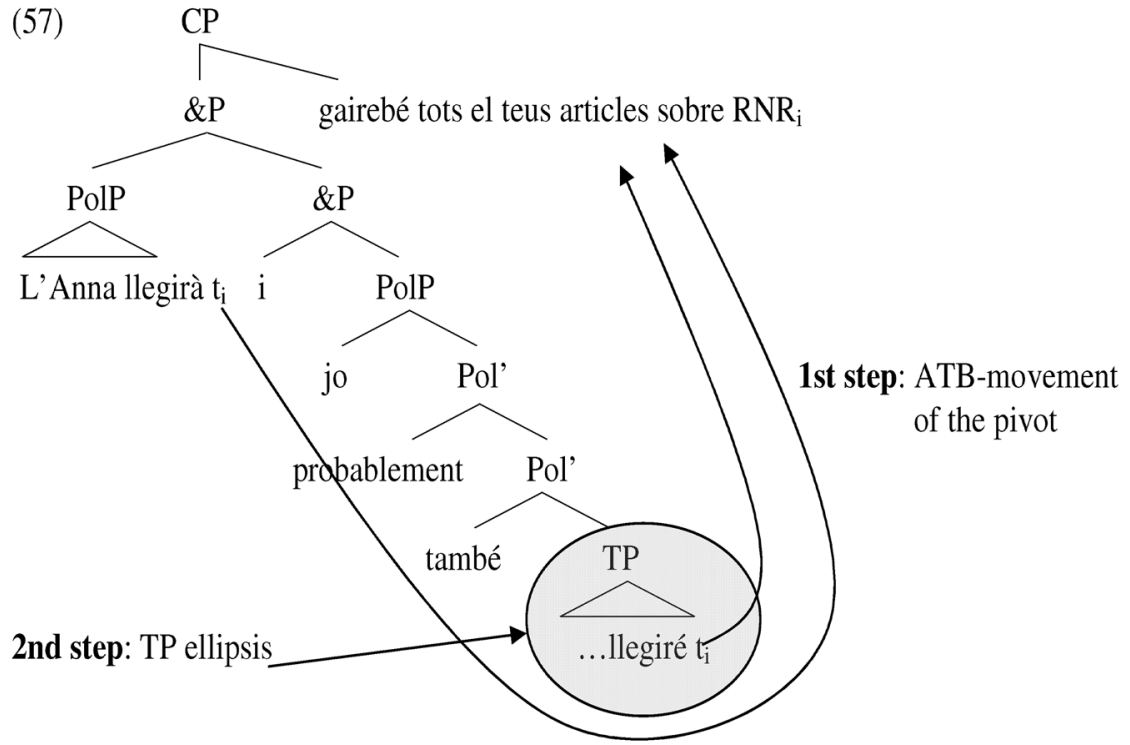

Another argument for an ATB-movement approach to FP-RNR comes from scope facts in contexts in which negation co-occurs with quantified pivots. (58) illustrates the Spanish facts: the preferred scope interpretation is that in which the quantified object takes scope over negation, which is expected if the quantified pivot has moved to a position from which it c-commands negation in both clauses. $^{7}$

(58) Ane no ha leído, y Juan no ha revisado, muchos artículos sobre Ane not has read and Juan not has revised many papers on RNR.

RNR

scope: muchos $>$ no; ??no $>$ muchos

Especially revealing in this respect is the behaviour of the Catalan quantifiers molts, gaires, and massa 'many'. Francesc Roca (p.c.) notices that quantifiers

7. An anonymous reviewer notices that NPI licensing facts like (i) might be problematic: if the pivot is not c-commanded by negation, NPIs should be banned from pivots.

(i) Ane no ha leído, y Juan no ha revisado, ningún artículo sobre RNR.

Ane not has read and Juan not has revised any paper on RNR

The solution here is reconstruction: the pivot can reconstruct to its original position in both conjuncts so that the NPI is c-commanded at LF. The obvious question then is why the reconstruction reading is less favoured for quantifier scope in (58). Notice that similar facts obtain in leftward focus movement, as illustrated in (ii) below.

(ii) a. NINGUNO de tus artículos no ha leído Ane.

b. MUCHOS de tus artículos no ha leído Ane.

muchos $>$ no, ??no $>$ muchos 
that have wide scope in contexts of negation like molts in (59a) can be pivots in FP-RNR (59c), whereas quantifiers like gaires/massa that have narrow scope (59b) can not (59d).

(59) a. L'Anna no ha llegit molts articles sobre RNR. molts $>$ no the+Anna not has read many papers on RNR

b. L'Anna no ha llegit gaires/massa articles sobre RNR. no > gaires/massa

c. L'Anna no ha llegit, i en Joan no ha revisat, molts articles the+Anna not has read and the Joan not has revised many papers sobre RNR.

on RNR

d. *?L'Anna no ha llegit, i en Joan no ha revisat, gaires/massa articles sobre RNR.

Williams (1978) observes that ATB-movement is subject to a structural parallelism requirement to the effect that the ATB-moved phrase must occupy the same structural position in both conjuncts prior to ATB-movement in non-embedded contexts. Although the ATB-moved who in (60a) can be extracted from a complement position in the first conjunct and from an embedded subject position in the second conjunct, this is impossible in the non-embedded coordinate clauses in (60b). Independently of how these facts are explained, I will use this structural parallelism requirement to show that FP-RNR involves ATB-movement of the pivot in C\&S.

(60) a. I know the man [ who $_{1}\left[\right.$ John likes $_{1}$ ] and [we hope $t_{1}$ will win]].

b. *I know a man [who ${ }_{1}\left[\right.$ Bill saw $\left.\mathrm{t}_{1}\right]$ and [ $\mathrm{t}_{1}$ likes Mary]].

[Williams (1978: 34)]

The parallelism requirement makes a clear prediction concerning the availability of ATB-movement in languages in which the subject does not have to move to Spec, TP and can thus stay in-situ, as is generally assumed for Catalan and Spanish. In these languages, ATB-movement is expected to be perfectly possible in contexts in which the moving phrase is an object in one conjunct and the subject of a passive or unaccusative predicate in the other, as the structural parallelism requirement will be satisfied due to the fact that the moving phrase occupies an object position in both conjuncts prior to ATB-movement. This is indeed the case, as illustrated in $(61 \mathrm{a}, \mathrm{b})$ for leftward ATB-movement. If the ATB-moved DP moves from Spec,vP in one conjunct and from the complement position in the other, as in $(61 \mathrm{c}, \mathrm{d})$, the structural parallelism condition is not satisfied, hence its deviance (examples from Catalan; the same applies to Spanish): 
(61) a. Quines mostres d'ADN dius que vas portar dilluns i no which samples of+DNA say.2sG that AUX bring monday and not van ser analitzades fins dijous?

AUX be analyzed until thursday

'Which DNA samples do you say you brought on Monday and were not analyzed until Thursday?'

b. Quines mostres d'ADN dius que et va enviar el jutge el which samples of+DNA say.2sG that you AUX send the judge the dimarts i van desaparèixer el dijous?

monday and AUX disappear the thursday

'Which DNA samples do you say that the judge sent on Tuesday and disappeared on Friday?'

c. ??Quines proves dius que vas trobar tu i van demostrar which evidence say.2sG that AUX find you and AUX show la seva culpabilitat?

the his guilt

'Which evidence do you say that you found at 10:00 and showed his guilt?'

d. ??Quines proves dius que demostraven la seva culpabilitat i which evidence say.2sG that showed the his guilt and vas destruir tu?

AuX destroy you

'Which evidence do you say that showed his guilt and you destroyed?'

If my claim that C\&S FP-RNR involves ATB-movement of the pivot is correct, similar structural parallelism facts should obtain. As shown in (62), this prediction is borne out. In (62a), the pivot is the object of a transitive verb in one conjunct and the subject of a passive verb in the other, and in (62b) it is the object of a transitive verb in one conjunct and the subject of an unaccusative verb in the other. So in these cases the structural parallelism condition is satisfied, as the pivot moves from an object position. Crucial for us is the deviance of $(62 \mathrm{c}, \mathrm{d})$, in clear parallelism with $(61 \mathrm{c}, \mathrm{d})$. In both cases the parallelism constraint on ATB-movement is violated. 
(62) a. Dilluns jo hi vaig dur, i dijous van ser analitzades, gairebé monday I LOC AUX bring and thursday AUX be analyzed almost el $70 \%$ de les mostres d'ADN. ( the $70 \%$ of the samples of $+\mathrm{DNA}$ 'On Monday I brought almost $70 \%$ of the DNA samples, and on Thursday they were analyzed.'

b. A les 10:00 el jutge ens va enviar, i hores després van at the 10:00 the judge us AUX send and hours later AUX desaparèixer, gairebé totes les mostres d'ADN. disappear almost all the samples of+DNA 'At 10:00 the judge sent us almost all the DNA samples, and a few hours later they disappeared.'

c. *Jo vaig trobar, i van demostrar la seva culpabilitat, força I AUX find and AUX show the his guilt abundant mostres d'ADN. samples of+DNA 'I found abundant DNA evidence, and that evidence demonstrated that he is guilty.'

d. *Demostraran la seva culpabilitat, i jo analitzaré, les mostres show.FUT the his guilt and I analyze.FUT the samples d'ADN trobades. of+DNA found 'The DNA evidence found will demonstrate that he is guilty, and I will analyze it.'

A second type of parallelism constraint that applies to ATB-movement is the requirement that the ATB-moved phrase match in case the gaps inside all the conjuncts of the coordination (Borsley 1983; Dyla 1984). In Spanish, this effect can be observed in the contrast between $(63 a)$ on the one hand and $(63 b, c)$ on the other. In (63a), the accusative DP matches the accusative case of the gaps inside the two conjuncts. In (63b), the accusative-marked wh-phrase matches the accusative case of the gap inside the first conjunct but not the nominative case of the gap in the second conjunct. The opposite happens in (63c). 
(63) a. ¿A qué traficante de heroína interrogó la policía el lunes DOM which dealer of heroin questioned the police the monday y encarceló el juez el martes? and imprisoned the judge the tuesday 'Which drug dealer did the police question on Monday and the judge imprison on Tuesday?'

b. ??¿A qué traficante de heroína interrogó la policía el lunes DOM which dealer of heroin questioned the police the monday y fue encarcelado el jueves? and was imprisoned the thursday

c. *QQué traficante de heroína interrogó la policía el lunes y fue encarcelado el jueves?

Catalan behaves differently in this respect. It has no Differential Object Marking (DOM) and (64), the equivalent of Spanish $(63 \mathrm{~b}, \mathrm{c})$, is thus grammatical because the same syncretic form is used for both nominative and accusative. However, DOM can sometimes show up in Catalan. If DOM is used, the Catalan examples corresponding to $(63 \mathrm{~b}, \mathrm{c})$ also exhibit case mismatch effects. ${ }^{8}$

(64) Quin traficant d'heroïna va interrogar la policia el dilluns i va which dealer of+heroin questioned the police the monday and was ser empresonat el dijous?

imprisoned the thursday

Notice that the ATB-moved phrases in both (61) and (62) are inanimate DPs for which also Spanish has syncretic forms for nominative and accusative, so that the case matching constraint is ultimately observed. Now if I am right that C\&S FP-RNR involves ATB-movement, similar case-matching effects should emerge. In the Spanish examples (65a) and (65b), where the pivot matches in accusative and nominative case respectively the case of the gaps in each conjunct, casematching is observed. The Catalan example corresponding to (65a) is also good with and without DOM in both clauses, as expected. In the Spanish examples in (66), on the contrary, case-matching is not observed, hence their deviance. As expected, the corresponding examples in Catalan are grammatical if there is no DOM, and the case mismatch effect emerges if DOM is used. The deviance of (66b) and (66d) also constitutes a powerful empirical argument against Peterson's (1999) parenthetical analysis of FP-RNR: if the pivot is in-situ in the first conjunct, the case marking of the pivot should be determined by the properties of the first conjunct, contrary to fact.

8. I thank Francesc Roca for this observation. 
(65) a. La policía interrogó, y el juez encarceló, a todos los the police questioned and the judge imprisoned DOM all the traficantes de heroína detenidos en la redada. dealers of heroin arrested in the raid

b. El lunes fueron detenidos, y el jueves fueron encarcelados, the monday were arrested and the thursday were imprisoned todos los traficantes de heroína detenidos en la redada. all the dealers of heroin arrested in the raid

(66) a. ??El lunes la policía interrogó, y el jueves fueron encarcelados, todos los traficantes de heroína detenidos en la redada.

b. *El lunes la policía interrogó, y el jueves fueron encarcelados, a todos los traficantes de heroína detenidos en la redada.

c. ??El lunes fueron detenidos, y el juez encarceló, a todos los traficantes de heroína detenidos en la redada. ${ }^{9}$

d. *El lunes fueron detenidos, y el juez encarceló, todos los traficantes de heroína detenidos en la redada.

Let us go back to Camacho's (2007) instances of Spanish RNR, repeated below for convenience. As I mentioned at the beginning of this section, the fact that the pivot in (67) is preceded by a comma suggests that we are dealing with a case of FP-RNR. The contrast between (67a) and (67b) actually supports the ex-situ analysis defended here for C\&S FP-RNR. Assuming Camacho's idea that propositional adverbs like siempre 'always' do not modify simplex DPs, (67b) is bad because the pivot is not a constituent and only constituents can undergo (ATB-)movement.

(67) a. ?Los niños traen $e_{i}, \mathrm{y}$ entregan siempre, [un regalo] $]_{\mathrm{i}}$. the children bring and deliver always a present

'The children bring, and always deliver, a present.'

b. *Los niños traen $e_{i}, \mathrm{y}$ entregan, [siempre un regalo] $]_{\mathrm{i}}$. the children bring $e_{i}$ and deliver always a gift

[Camacho (2003: 25-26)]

The examples that Camacho uses to argue against an ex-situ pivot approach to RNR are reproduced in (68) and (69). They show that the PP pivot must satisfy the selectional restrictions of the verb in the second conjunct, which is unexpected if it has ATB-moved. As I noticed at the beginning of this section, the fact that these examples do not feature a comma before the pivot suggests that they are instances of NFP-RNR, not FP-RNR.

9. Some speakers consider (66a) and (66c) to be better than indicated in the text. This is probably due to the proximity of the gap of the second conjunct in linear order. 
(68) a. Desde aquel día fue y vino del Instituto. from that day went and came of-the Institute 'From that day he/she went and came from the institute.'

b. Primero amedrentaron y luego dispararon contra los manifestantes. first harassed and then shot against the demonstrators 'First they harassed, and then they shot at the demonstrators.'

[Camacho (2003: 158)]

(69) a. *Desde aquel día vino y fue del Instituto. from that day came and went of-the Institute

b. *Primero dispararon y luego amedrentaron a los manifestantes. first shot and then harassed to the demonstrators

[Camacho (2003: 158)]

Interestingly, the corresponding FP-RNR examples are deviant (70), the reason being that they constitute a lack of parallelism effect on ATB-movement of the pivot similar to the case matching effects considered above. Camacho's examples thus actually support my proposal that there are two types of RNR with different focal, prosodic, and syntactic properties.

(70) a. *Desde aquel día fue, y vino, del instituto.

b. *Primero amedrentaron, y luego dispararon, contra los manifestantes.

The conclusion is thus that the properties of C\&S FP-RNR are better explained by an ex-situ ATB-movement analysis. I now turn to C\&S NFP-RNR.

\subsection{Catalan and Spanish NFP-RNR}

I will first try to correctly identify instances of NFP-RNR in C\&S. I will first look at cases of ellipsis in the first conjunct of a coordinate structure that might be considered to be instances of FP-RNR but which, I argue, should not be considered when analyzing the properties of C\&S NFP-RNR. Remember that the crucial property of RNR discussed above when considering English RNR is that the gap can only occur in the first conjunct.

The example in (71a) is superficially a case of RNR with a complex pivot containing the verbal complex and the internal argument of the verb. But notice that the gap can also appear in the second conjunct (71b), which is unexpected if (71a) is a case of RNR. Assuming that preverbal subjects in C\&S occupy a position outside TP, I consider that these examples should be analyzed as instances of TP ellipsis, not as canonical cases of NFP-RNR (Catalan examples; the same applies to Spanish, 
(71) a. Uns diuen que en Lluís_ _ i d'altres diuen que la Miren some say that the Lluís and of+others say that the Miren guanyarà les eleccions. win.FUT the elections.

b. Uns diuen que la Miren guanyará les eleccions, i d'altres diuen que en Lluís

The example in (72a) in which there is a gap corresponding to the non-finite verb and its complement in the first conjunct should not be considered to be a case of NFP-RNR, either; as shown in (72b), the gap can appear in the second conjunct. These are probably instances of Null Complement Anaphora.

(72) a. Uns volen _ i d'altres no volen assumir les despeses some want and of +others not want assume the costs addicionals. extra

'Some want and others don't want to assume the extra costs.'

b. Uns volen assumir les despeses addicionals, i d'altres no volen

When checking the properties of C\&S NFP-RNR, I will thus only consider those instances of gaps in the non-final conjunct of a coordination that do not have a corresponding grammatical counterpart with the gap in the final conjunct. Catalan and Spanish are not null object languages, so cases of object DPs as pivots can only be instances of FP-RNR.

In (73), an object DP is missing in the first conjunct of the coordination, but cases like these in which there is only one overt subject could be argued to involve coordination of the verbal heads. So they do not qualify as real cases of NFP-RNR.

(73) En Joan està arrebossant _ ${ }^{i}$ fregint el lluç. the Joan is breading - and frying the hake

(74) clearly is not an instance of coordination of heads, as the tense specification is different for each verb, an indication that it involves coordination of two TPs. So this is an unambiguous instance of NFP-RNR.

(74) Els comerciants han tingut _, tenen _ i tindran el meu suport. the shopkeepers have had have and have.Fut the my support

Actually, although in the literature it is typically assumed that RNR involves coordination of TPs, there is empirical evidence that some examples must involve coordination of two CPs, as wh-movement of the indirect object is possible in both conjuncts: 
(75) M'agradaria saber a qui ${ }_{i}$ vau deixar _ $t_{i} i$ a qui $i_{j}$ vau donar me+like.COND know to who AUX lend and to who AUX give diners $t_{j}$.

money

'I would like to know to whom you lent and to whom you gave money.'

In contexts in which each member of the coordination contains a different subject, the results are perfect when the subjects are identical wh-words (76a) but there is cross-speaker variation in contexts of different non-wh subjects (76b). The speakers who reject (76b) propose sentences with object clitics as alternatives (76c). If the verb before the gap and the pivot receives very prominent focal stress in (76b), it is judged to be better by those speakers who initially reject it.

(76) a. M'agradaria saber qui va arrebossar_ _ i qui va fregir el me+like.COND know who AUX bread and who Aux fry the lluç. hake

'I would like to know who breaded and who fried the hake.'

b. \%Em sembla recordar que en Joan va arrebossar _ i que me seem remember that the Joan AUX bread and that la Miren va fregir el lluç. the Miren Aux fry the hake 'As far as I can remember, Joan breaded and Miren fried the hake.'

c. Em sembla recordar que en Joan va arrebossar el lluç i me seems remember that the Joan AUX bread the hake and que la Miren el va fregir.

that the Miren it AUX fry

'As far as I can remember, Joan breaded the hake and Miren fried it.'

DP complements of prepositions can be omitted in a context like (77a), but again this should probably be analyzed as coordination of two heads and not as a case of NFP-RNR. In clear contexts of TP coordination like (77b), there is again crossspeaker variation, with considerable improvement if very prominent focal stress falls on the prepositions immediately preceding the gap and the pivot. In contexts in which the two prepositions are not in a contrastive relation and are thus unlikely to receive focal stress, FP-RNR is unanimously considered to be impossible (78).

(77) a. Ho pots fer amb_ o sense sucre.

it can.2sG do with or without sugar

'You can make it with or without sugar.'

b. \%En Pere ho va fer amb_i l'Andreu ho va fer sense the Pere it AUX do with and the+Andreu it AUX do without sucre.

sugar

'Pere made it with and Andreu made it without sugar.' 
(78) a. *No parli amb _ ni distregui l'atenció del conductor si not speak with nor distract the+attention of-the driver if l'autobús està en marxa.

the+bus is in motion

'Do not speak to or distract the attention of the driver while the bus is moving.'

b. ${ }^{*}$ La Miren va estudiar amb_i va treballar per a la Susanna. the Miren AUX study with and AUX work for the Susanna

The possibility of having DP complements of prepositions illustrated in (77b,) indicates that the pivot is in-situ in NFP-RNR, as C\&S are not preposition-stranding languages.

Now if my claim that the pivot is in-situ in NFP-RNR is correct, an immediate consequence is that parasitic gaps should not be licensed in those contexts. This is indeed the case (79).

(79) a. *En Joan va IGNORAR, i en Pere va LLEGIR sense the Joan AUX ignore and the Pere AUX read without entendre $[e]_{\mathrm{PG}}$ els teus articles.

understand the your papers

b. *Joan IGNORÓ y Pere LEYÓ sin entender $[e]_{\mathrm{PG}}$ tus Joan ignored and Pere read without understand your artículos.

papers

An additional fact that is immediately explained if the pivot is in-situ in C\&S NFP-RNR is the impossibility of having TP-ellipsis in these contexts (80), in clear contrast with the FP-RNR data shown in (55)-(56) above. Independently of whether one adopts an ellipsis (81) or multidominance (82) approach to NFP-RNR, the insitu pivot will inevitably be eliminated when the TP is deleted.

(80) a. *L'Anna llegirà però jo NO els teus articles. the+Anna read.Fut but I not the your papers

b. *Anna leerá pero yo NO tus artículos. Anna read.Fut but I not your papers 
$(81)$

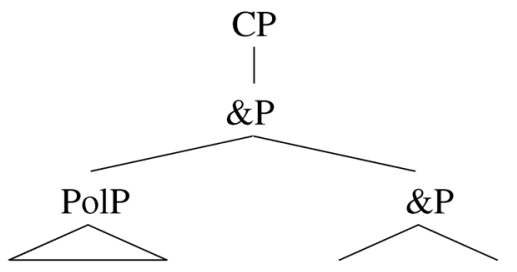

L'Anna llegirà erò

PolP

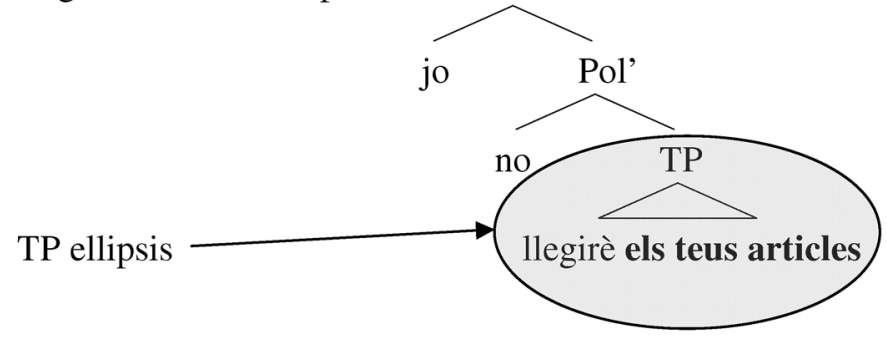

(82)

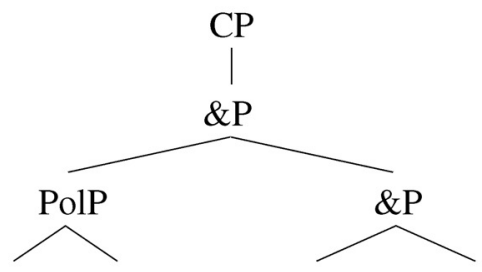

L'Anna<smiles>C[In](C)C</smiles>

però
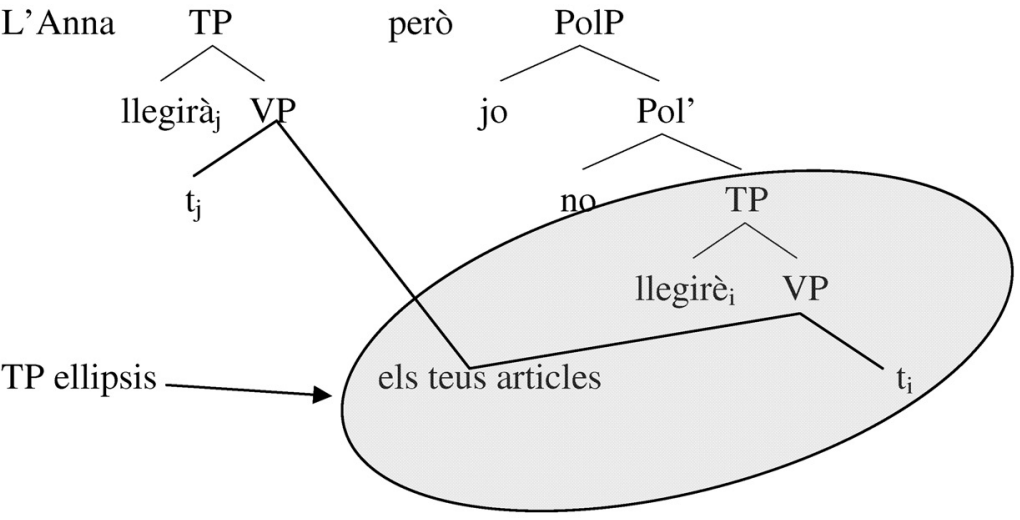

Two conclusions can be drawn from this section. The first is that C\&S NFPRNR involves an in-situ pivot, the gap in the first conjunct resulting either from ellipsis of material identical to the pivot in the first conjunct or from not pronouncing the multidominated pivot in that position. The second is that C\&S NFP-RNR is dependent on the existence of focal material preceding the pivot. The second conclusion suggests that C\&S NFP-RNR is more likely to be analyzed as an instance 
of ellipsis in the first conjunct, which in the general case is known to be related to focal structure (see Merchant 2001, among others). It is not clear why Parallel Merge, if it is one of the possible structure-building mechanisms allowed by UG, should be restricted to contexts of focus.

\section{Conclusions}

I have shown that Catalan and Spanish have two types of RNR structures: Focal-Pivot RNR (FP-RNR) and Non-Focal-Pivot RNR (NFP-RNR). In the former, the pivot is focal, preceded by a prosodic break, and features ATB-movement of the pivot. The gap in the first conjunct of FP-RNR is thus a variable. In the latter, the pivot is not focal, not preceded by a prosodic break, and in-situ, and the gap in the first conjunct results either from ellipsis of material identical to the pivot or from not pronouncing the multidominated pivot in that position.

\section{References}

Abbott, Barbara (1976). «Right Node Raising as a test for constituenthood». Linguistic Inquiry 7: 639-742.

Abe, Jun; Hornstein, Norbert (2012). «'Lasnik-Effects’ and string-sacuous ATB movement». In: Uribe-Etxebarria, Myriam; Valmala, Vidal (eds.). Ways of structure building. Oxford: OUP, pp. 169-205.

Abels, Klaus (2004). «Right Node Raising: Ellipsis or across the board movement». In: Moulton, Keir; Wolf, Matthew (eds.). Proceedings of NELS 34. Amherst: GLSA, pp. 45-60.

Altshuler, Daniel; Déprez, Viviane (2007). «Parenthetical null topic constructions in Romance». In: Camacho, José; Flores-Ferrán, Nydia; Sánchez, Liliana; Déprez, Viviane; Cabrera, María José (eds.). Romance Linguistics 2006. Amsterdam: John Benjamins. pp. 1-14.

An, Du-Ho (2008). «Lower pronunciation and multiple wh-fronting in ATB contexts». Nanzan Linguistics 3.2: 1-15.

Bachrach, Asaf; Katzir, Roni (2009). «Right-Node Raising and delayed spellout». In: Grohmann, Kleanthes (ed.). Interphases: Phase-theoretic investigations of linguistic interfaces. Oxford: OUP, pp. 283-316.

Barros, Matthew; Vicente, Luis (2010). «Right Node Raising requires both multidominance and ellipsis». Handout of the presentation at the Penn Linguistics Colloquium (March 19-21). http://eden.rutgers.edu/ mattb13/images/PLC34RNRMDE.pdf

Borsley, Robert (1983) «A note on the Generalized Left Branch Condition». Linguistic Inquiry 14: 169-174.

Bošković, Željko (2004). «Two notes on Right Node Raising». University of Connecticut Working Papers in Linguistics 12: 13-24.

Camacho, José (2003). The structure of coordination. Kluwer.

Cann, Ronnie; Kempson, Ruth; Marten, Lutz; Otsuka, Masayuki (2005). «Right Node Raising, coordination and the dynamics of language processing». Lingua 115: 503-525. 
Chae, Hee-Rahk (1991). «Right Node Raising and a LICENSOR feature». Proceedings of the 27th Meeting of the Chicago Linguistic Society. The University of Chicago Press.

Chalcraft, Faye. (2006). «Right Node Raising as ellipsis: evidence from (what the) British do». Snippets 12.

Clapp, Jessica M. (2008) «Right Node Raising: Evidence from 'Rule Interaction'». In: Chang, Charles B.; Haynie, Hannah J. (eds.). Proceedings of the 26th WCCFL. Somerville, MA: Cascadilla Press. pp. 129-137.

Dougherty, Ray (1970). «A grammar of coordinate conjoined structures I». Language 46.4: 850-898.

Dyla, Stefan (1984). «Across-the-board dependencies and case in Polish». Linguistic Inquiry 15: 701-705.

Erteschik-Shir, Nomi (2010). «Linearizing parallel structures: focus and silence». Handout of a talk presented at the seminar of the Hebrew University of Jerusalem.

Féri, C. ; Hartmann, Katharina (2003). «The focus and prosodic structure of German Right Node Raising and gapping». The Linguistic Review 22: 69-116.

Florez, Óscar. (1985). «La regla de enlace y la entonación en español». Thesaurus XL, number 2: 308-327.

Fox, Daniel. (2000). Economy and semantic interpretation. Cambridge, MA: MIT Press.

Grosu, Alexander (1976). «A note on subject raising to object and Right Node Raising». Linguistic Inquiry 7: 642-645.

Ha, Seungwan (2008). «On ellipsis features and Right Node Raising». Proceedings of ConSOLE XV, pp. 67-90.

Ha, Seungwan (2009). «Multiple dominance CAN'T, but ellipsis CAN account for Right Node Raising». Proceedings from the 42nd Annual Meeting of the Chicago Linguistic Society 42.1: 17-31.

Hartmann, Katharina (2000). Right Node Raising and gapping: Interface conditions on prosodic deletion. Amsterdam: John Benjamins.

Hartmann, Katharina (2003). «Background matching in Right Node Raising constructions». In: Schwabe, Kerstin; Winkler, Susanne (eds.). The Interfaces. Amsterdam: John Benjamins, pp. 121-151.

Hornstein, Norbert; Nunes, Jairo (2002). «On asymmetries between parasitc gap and across-the-board constructions». Syntax 5.1: 26-54.

Hudson, Richard (1976). «Conjunction reduction, gapping and right-node raising». Language 52: 535-562.

Kayne, Richard (1994). The antisymmetry of Syntax. Cambridge, MA: MIT Press.

Koutsoudas, Andreas (1971). «Gapping, coordinate reduction and coordinate deletion». Foundations of Language 7: 337-386.

Levine, Robert (1985). «Right node (non-)raising». Linguistic Inquiry 16: 492-497.

Maling, Joan (1972). «On gapping and the order of constituents». Linguistic Inquiry 3: 101-108.

McCawley, James D. (1982). «Parentheticals and discontinuous constituent structure». Linguistic Inquiry 13: 91-106.

McCawley, James D. (1988). The syntactic phenomena of English. Chicago: University of Chicago Press.

McCloskey, James (1986). «Right Node Raising and preposition stranding». Linguistic Inquiry 17: 183-186. 
Merchant, Jason (2001). The syntax of silence. Oxford: OUP.

Merchant, Jason (2004). «Fragments and ellipsis». Linguistics and Philosophy 27: 661-738.

Peterson, Peter (1999). «On the boundaries of syntax: Non-syntagmatic relations». In: Collins, Peter; Lee, David (eds.). The clause in English. Amsterdam: John Benjamins, pp. 229-250.

Phillips, Colin (2003). «Linear order and constituency». Linguistic Inquiry 34: 37-90.

Postal, Paul M. (1974) On raising. Cambridge, MA: MIT Press.

Postal, Paul M. (1994). «Parasitic and pseudoparasitic gaps». Linguistic Inquiry 25: 63-117.

Postal, Paul M. (1998). Three investigations of extraction. Cambridge, MA: MIT Press.

Ross, John Robert (1967). Constraints on variables in syntax. MIT, doctoral dissertation.

Sabbagh, Joseph (2007). «Ordering and linearing rightward movement». Natural Language and Linguistic Theory 25: 349-401.

Selkirk, Elisabeth (2002). «Contrastive FOCUS vs. presentational focus: Prosodic evidence from Right Node Raising in English». Speech prosody 2002, pp. 643-646.

Sohn, Keun-Won, (2001). «Deletion and Right Node Raising in Korean and English». Studies in Generative Grammar 11.2: 485-503.

Valmala, Vidal (2012). «Two types of Right Node Raising». UVP/EHU, unpublished manuscript.

de Vries, Mark (2012). «Unconventional mergers». In: Uribe-Etxebarria, Myriam; Valmala, Vidal (eds.). Ways of structure building. Oxford: OUP, pp.143-166.

Wexler, Kenneth; Culicover, Peter W. (1980). Formal principles of language acquisition. Cambridge, MA: MIT Press.

Wilder, Chris (1999). «Right Node Raising and the LCA». In: Bird, Sonya; Carnie, Andrew; Haugen, Jason D.; Norquest, Peter (eds.). Proceedings of the 18th WCCFL. Somerville, MA: Cascadilla Pres, pp. 586-598.

Williams, Edwin (1978). «Across-the-board rule application». Linguistic Inquiry 9: $31-43$

Zhang, Niina Ning (2004). «Against across-the-board movement». Concentric: Studies in Linguistics 30: 123-156. 
